\title{
Correspondence
}

To the Editors

\section{Dengue and COVID-19, overlapping epidemics in highly endemic area}

Sri Lanka Journal of Child Health, 2020; 49(4): 419

DOI: http://dx.doi.org/10.4038/sljch.v49i4.9286

(Key words: COVID, dengue, epidemics)

Dear Editor,

COVID-19 is the important pandemic at present. There are several millions of patients of COVID-19 around the world. In the tropical zone, this disease might co-exist with other common endemic tropical infections. Of several tropical diseases, dengue is an important disease that is widely mentioned in an inter-relationship with COVID-19. Clinically, COVID-19 shares a common clinical spectrum with dengue and it might lead to difficulties in diagnosis ${ }^{1}$. The co-existence between dengue and COVID-19 is also possible ${ }^{2}$.

Here, the authors present the data from one of the areas with the highest incidence of dengue in Indochina, the North-Eastern region of Thailand. The Scatterplot incidence of dengue versus incidence of COVID-19 is presented in Figure 1. From correlation analysis, there is a significant correlation $(p<0.001, r=0.707)$. This finding can confirm a recent report from Colombia that there are overlapping epidemics between COVID-19 and dengue $^{2}$. In a tropical country, children might be affected by both COVID-19 and dengue at the same time. It is recommended that the practitioner should recognize the clinical similarity between the two diseases and the possible concurrence of the two infections ${ }^{3}$.

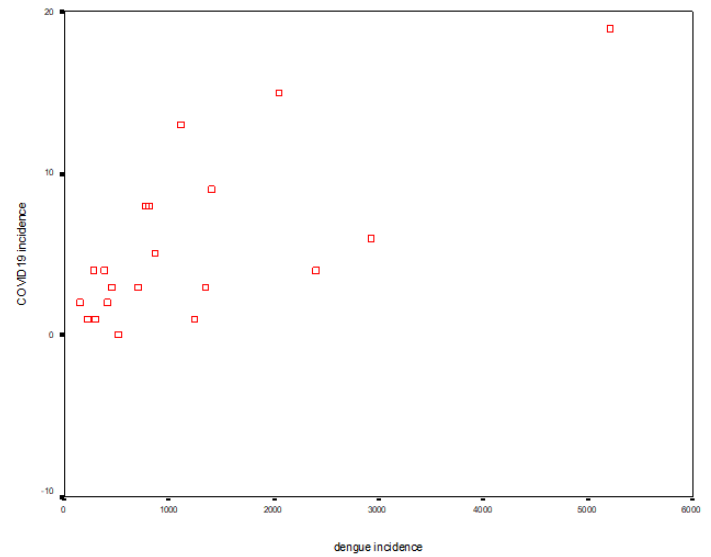

Figure 1: Scatterplot incidence of dengue versus incidence of COVID-19

\section{References}

1. Joob B, Wiwanitkit V. COVID-19 can present with a rash and be mistaken for dengue. Journal of the American Academy of Dermatology 2020; 82(5): e177. https://doi.org/10.1016/j.jaad.2020.03.036 PMid: 32213305 PMCid: PMC7156802

2. Cardona-Ospina JA, Arteaga-Livias K, Villamil-Gómez WE, Pérez-Díaz CE, Katterine Bonilla-Aldana D, MondragonCardona Á, et al. Dengue and COVID-19, overlapping epidemics? An analysis from Colombia. Journal of Medical Virology 2020:10.1002/jmv.26194.

https://doi.org/10.1002/jmv.26194

PMid: 32558962 PMCid: PMC7323437

3. Joob B, Wiwanitkit V. Reply to: Various forms of skin rash in COVID-19: Petechial rash in a patient with COVID-19 infection. Journal of the American Academy of Dermatology 2020; 83(2): e143.

https://doi.org/10.1016/j.jaad.2020.04.035 PMid: 32283235 PMCid: PMC7151475

\footnotetext{
*Beuy Joob ${ }^{1}$, Viroj Wiwanitkit ${ }^{2}$

${ }^{1}$ Private Academic Consultant

${ }^{2}$ Honorary Professor, Dr. DY Patil University, Pune, India

*Correspondence: beuyjoob@hotmail.com

iD. orcid.org/ 0000-0002-5281-0369
} 